Research Paper

\title{
A Systematic Review and Meta-Analysis of Randomized Trials and Prospective Studies Comparing Covered and Bare Self-Expandable Metal Stents for the Treatment of Malignant Obstruction in the Digestive Tract
}

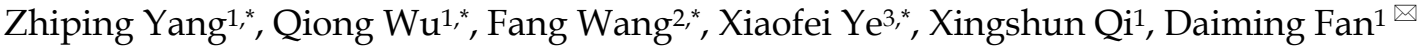 \\ 1. Xijing Hospital of Digestive Diseases, Fourth Military Medical University, Xi'an, China; \\ 2. Department of Gastroenterology, Affiliated Hospital of Ningxia Medical University, Yinchuan, China; \\ 3. Department of Health Statistics, Second Military Medical University, Shanghai, China. \\ * These authors contributed equally to this work.
}

$\square$ Corresponding author: Daiming Fan, Xijing Hospital of Digestive Diseases, Fourth Military Medical University, 127 West Changle Road, Xi'an 710032, China. Tel: 86-29-84771501; Fax: 86-29-82539041; E-mail: daimingfan@fmmu.edu.cn.

() Ivyspring International Publisher. This is an open-access article distributed under the terms of the Creative Commons License (http://creativecommons.org/ licenses/by-nc-nd/3.0/). Reproduction is permitted for personal, noncommercial use, provided that the article is in whole, unmodified, and properly cited.

Received: 2013.01.28; Accepted: 2013.04.16; Published: 2013.04.27

\begin{abstract}
Background: Self-expandable metal stents (SEMS) are widely used for the palliative treatment of malignant gastrointestinal obstruction. Our aim was to evaluate the evidence comparing covered and bare SEMS in the digestive tract using meta-analytical techniques.

Methods: A literature search was performed using PubMed, Cochrane Library, and Embase databases for comparative studies assessing the two types of stents. The primary outcomes of interest were stent patency and patient survival; second outcomes included technical success, clinical success, tumor ingrowth, tumor overgrowth, and stent migration. A random-effects model was conducted. Pooled analysis was done separately based on the different segments of the digestive tract.

Results: Eleven studies ( 8 randomized controlled trials and 3 prospective cohort studies) including a total of 1376 patients were identified. Covered SEMS were equivalent to bare SEMS in terms of technical success, clinical success, stent patency (gastroduodenal obstruction: $\mathrm{HR}=0.87$, $95 \% \mathrm{Cl}$ 0.53-1.42; colorectal obstruction: $\mathrm{HR}=0.89,95 \% \mathrm{Cl} 0.18-4.45$; biliary obstruction: $\mathrm{HR}$ $=0.73,95 \% \mathrm{Cl} 0.4 \mathrm{I}-\mathrm{I} .32$ ) and survival rates (esophageal obstruction: $\mathrm{HR}=1.80,95 \% \mathrm{Cl} 0.73-4.44$; gastroduodenal obstruction: $\mathrm{HR}=0.83,95 \% \mathrm{Cl} 0.55-1.26$; biliary obstruction: $\mathrm{HR}=0.99,95 \% \mathrm{Cl}$ 0.77-1.28), although bare stents were more prone to tumor ingrowth (esophageal obstruction: RR $=0.10,95 \% \mathrm{Cl} 0.01-0.77$; gastroduodenal obstruction: $R R=0.12,95 \% \mathrm{Cl} 0.03-0.55$; colorectal obstruction: $R R=0.21,95 \% \mathrm{Cl} 0.06-0.70$; biliary obstruction: $R R=0.21,95 \% \mathrm{Cl} 0.06-0.69$ ), whereas covered stents had the higher risk of stent migration (gastroduodenal obstruction: RR $=5.01,95 \% \mathrm{Cl}$ I.53-16.43; colorectal obstruction: $\mathrm{RR}=1 \mathrm{I} .70,95 \% \mathrm{Cl} 2.84-48.27$; biliary obstruction: $\mathrm{RR}=8 . \mathrm{II}, 95 \% \mathrm{Cl}$ I.47-44.76) and tumor overgrowth (biliary obstruction: $\mathrm{RR}=2.03,95 \% \mathrm{Cl}$ I.08-3.78).

Conclusion: Both covered and bare SEMS are comparable in efficacy for the palliative treatment of malignant obstruction in the digestive tract. Each type of the stents has its own merit and demerit relatively.
\end{abstract}

Key words: covered stent; digestive tract; gastrointestinal cancer; malignant obstruction; self-expandable metal stent. 


\section{Introduction}

Stenting has become a promising option for the treatment of malignant obstruction due to cancer in the digestive tract, which plays a vital role in alleviating obstructive symptoms such as dysphagia and jaundice, and improving patients' quality of life. Nowadays, self-expandable metal stents (SEMS) are widely used in the upper gastrointestinal, lower gastrointestinal, and biliary tracts [1,2]. It has been proved that SEMS are superior to plastic stents in terms of patency rate $[3,4]$. However, when it concerns to the two types of SEMS (covered stents and bare stents), no consensus is reached on which one is the first choice. Compared with bare stents, covered stents have been developed to minimize tumor in growth through the metal mesh but have a higher rate of stent migration. The prevention of tumor ingrowth and the risk of migration are two sides of the same coin of covered stents [5-8]. Whether covered stents gain the advantage over bare stents should depend on the long-term patency and survival rates after stent placement in patients with gastrointestinal obstruction, which is still controversial.

Two recently published meta-analyses displayed conflicting results about stent patency. One concerning the palliation of distal malignant bile duct obstruction suggested that covered SEMS were associated with significantly prolonged stent patency [9]. While the other concerning malignant large bowel obstruction showed uncovered SEMS had a prolonged stent patency [10]. Another meta-analysis comparing different types of esophageal stents for malignant dysphagia did not give any results with regard to patency and survival between covered and uncovered stents [4].

The general principle of SEMS is to provide a lumen after placement in any malignant luminal obstruction, and this principle is the same throughout the entire digestive tract. Tissue responses to the stents are fairly similar in the digestive tract. Moreover, the design of the stents is similar for esophagus, pylorus/duodenum, colon and rectum, and bile duct. Therefore, we performed a comprehensive systematic review with meta-analysis to determine the clinical efficacy of covered versus bare SEMS for the palliative treatment of malignant obstruction in all digestive tract segments.

\section{Materials and Methods}

\section{Search strategy}

PubMed, Cochrane Library, and Embase databases were searched until September 2012 by two independent investigators (Z.Y. and X.Y.). Compara- tive studies were identified using the following key words (the full electronic search strategy for PubMed database was seen in the supplemental material): covered stent AND (occlusion OR stenosis OR obstruction OR stricture OR obliteration OR stasis). The computer search was supplemented with a manual search of reference lists for all available review articles and primary studies. There were no language restrictions. Only randomized controlled trials (RCTs) and prospective cohort studies (PCSs) were included.

\section{Inclusion and exclusion criteria}

Two reviewers (Z.Y. and Q.W.) independently screened the titles and abstracts of studies to identify those that fulfilled the inclusion criteria: a) population: patients with cancerous obstruction in any position of the digestive tract; b) intervention: covered SEMS placement for the palliative treatment; c) comparator: bare SEMS placement; d) outcomes: studies were required to describe data related to at least one of the following primary endpoints of tumor ingrowth, tumor overgrowth, stent migration, stent patency, and patient survival. The interobserver agreement of the two authors (Z.Y. and Q.W.) was rated by calculation of Kappa value. Any disagreement was resolved by discussion between the two reviewers.

We excluded studies if their research nature was retrospective, and if it was absent to evaluate any endpoint of interest or impossible to calculate these from published results.

\section{Outcomes and definitions}

The primary outcomes assessed in this meta-analysis were stent patency (hazard ratio [HR] for time from initial insertion to recurrence of obstruction) and patient survival (HR for death). We did not use weighted mean difference like the previous meta-analyses as effect measure for patency and survival. Because the included studies in the both meta-analyses had various length of follow-up, not in a uniform period such as one year, and the observational events might not occur in some patients at the end of study. For these time-to-event outcomes, HR is the most common summary measure [11].

The secondary outcomes were rates of technical success, clinical success, tumor ingrowth, tumor overgrowth, and stent migration. Technical success was defined as the accurate position of a stent across the entire length of the stricture. The definition of clinical success was the relief of obstructive symptoms without immediate stent-related complications. Tumor ingrowth was defined as growth of the tumor invading the body of the stent and occluding its lumen. Tumor overgrowth was defined as growth of the 
tumor proximal or distal to the stent and leading to lumen occlusion with function loss. Stent migration was considered if the stent moved from its initially located position and then could not cover the entire stenotic portion. A portion of patients with malignant colorectal obstruction (39.1\%) were inserted SEMS as a bridge to surgery. They were not included in the calculation of any observational endpoint except for technical and clinical success.

\section{Data extraction and quality assessment}

Two reviewers (Z.Y. and Q.W.) independently extracted data of the selected studies using a predefined form, discrepancies were arbitrated by a third reviewer (F.W.). Data related to the outcomes, methodological quality, first author, year of publication, country of origin, study design, indication for stents, malignant tumors, number of patients with covered and uncovered stents, patients' characteristics, length of follow-up, type of covered and bare SEMS, and covering material were collected. The HR for time-to-event outcome was calculated using the Excel sheet published by Tierney et al [12], based on Parmar's method of data extraction from Kaplan-Meier curves [13] as it was not reported in all the included studies, and individual patient data was not available for any study. The probabilities of patency and survival at each time point for each treatment group were transcribed from the Kaplan-Meier curves using the tools of line drawing and distance measure in the Adobe Acrobat 7.0 Professional software (Adobe Systems Incorporated, San Jose, CA, USA).

We evaluated study quality by using a modified established standard based on adequate sequence generation, allocation concealment, and blinding, incomplete outcome data addressed, free of selective reporting, free from baseline imbalance, free from early stopping, sample size calculation, and free from sources of funding bias [14]. Each quality component was rated as yes, unclear, or no. The quality of studies was reported according to each separate component.

\section{Statistical analysis}

Relative risk (RR) or HR with $95 \%$ confidence interval (CI) were estimated as summary statistics for dichotomous outcomes and time-to-event outcomes respectively. It was considered statistically significant if $\mathrm{P}<0.05$ or the $95 \% \mathrm{CI}$ did not contain the value 1 . We performed the pooled analysis using the random-effects model, in which it is assumed that there is variation among studies in terms of methodological or clinical characteristics. Thus it is overall a more conservative approach than the fix-effects model [15]. To investigate for statistical heterogeneity between studies, the $\chi^{2} \mathrm{Q}$-test $(\mathrm{P}<0.10$ was considered to represent significant heterogeneity) and the $\mathrm{I}^{2}$ statistic ( $>50 \%$ was considered as having substantial heterogeneity) were applied. Pooled analysis was performed separately in each segment of the digestive tract, but the results for each endpoint were shown together in one figure. Publication bias across the studies was assessed with Egger regression test. All analyses listed above were conducted using the software Reviewer Manager (version 5.1; Copenhagen: The Nordic Cochrane Centre, The Cochrane Collaboration, 2011) and Stata (version 12.0; Stata Corporation, College Station, TX, USA).

\section{Results}

\section{Description of studies}

After the initial search, 4062 potentially relevant references were identified. We excluded 4031 references after a review of their titles and abstracts suggested that they did not meet inclusion criteria and retrieved the remaining 31 studies for more detailed evaluation. After further reviews for eligibility, a total of 11 studies were identified finally [16-26], of which 8 were RCTs and 3 were PCSs (Figure 1). Kappa values for the interobserver agreement between the two reviewers (Z.Y. and Q.W.) were 0.86 , which indicated substantial agreement.

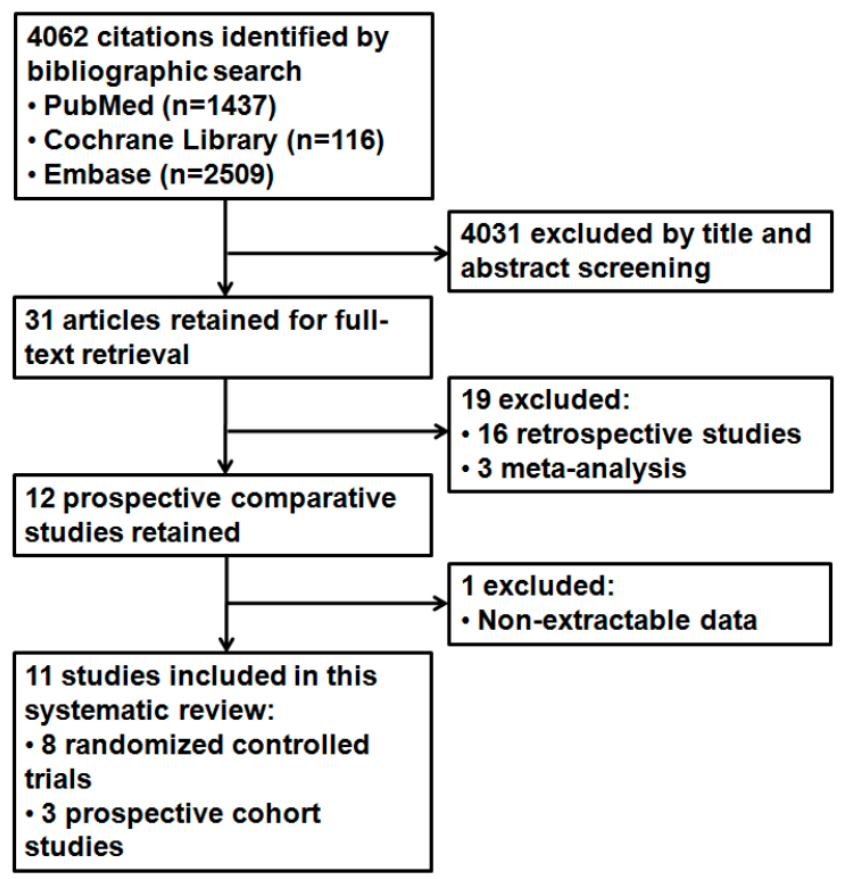

Fig I. Study flow diagram.

All the 11 studies published between 2001 and 2011 compared 684 in the covered and 692 in the bare SEMS (total of 1376 patients). Five studies were from 
the Western countries [16, 23-26], while the others were from the Far East [17-22]. Seven of the studies were multicenter $[16,20,22-26]$. The numbers of studies for esophageal, gastroduodenal, colorectal, and biliary stents were $1,2,3,5$, respectively. The major causes of these four kinds of obstruction were esophageal cancer $(84 \%)$, gastric cancer $(86 \%)$, colorectal cancer $(86 \%)$, and pancreatic cancer $(72 \%)$, respectively. Important details about patient and stent characteristics are shown in Table 1.

Table I. Study Characteristics.

\begin{tabular}{|c|c|c|c|c|c|c|c|c|c|c|}
\hline Study & Country & Design & $\begin{array}{l}\text { Indication } \\
\text { for stents }\end{array}$ & Malignant tumors (n) & $\begin{array}{l}\text { No. of } \\
\text { patients }\end{array}$ & $\begin{array}{l}\text { Mean } \\
\text { age, y }\end{array}$ & $\begin{array}{l}\text { Male } \\
\text { gen- } \\
\text { der, \% }\end{array}$ & $\begin{array}{l}\text { Follow-up } \\
\text { (range) }\end{array}$ & Stent type & $\begin{array}{l}\text { Covering } \\
\text { material }\end{array}$ \\
\hline $\begin{array}{l}\text { Vakil et } \\
\text { al., } \\
2001[16]\end{array}$ & $\begin{array}{l}\text { USA, UK, } \\
\text { Canada, } \\
\text { Italy, } \\
\text { Germany }\end{array}$ & $\begin{array}{l}\text { RCT (Mul- } \\
\text { ti-center) }\end{array}$ & $\begin{array}{l}\text { Esophageal } \\
\text { obstruction }\end{array}$ & $\begin{array}{l}\text { Majority of adeno- } \\
\text { carcinoma at the } \\
\text { gastroesophageal } \\
\text { junction (52) }\end{array}$ & $32 / 30$ & $74 / 71$ & NA & $\begin{array}{l}\text { Until dead or } \\
\text { for } 6 \text { months }\end{array}$ & NA & $\begin{array}{l}\text { NA } \\
\text { (Partially) }\end{array}$ \\
\hline $\begin{array}{l}\text { Lee et al., } \\
2009[17]\end{array}$ & Korea & $\begin{array}{l}\text { PCS (Sin- } \\
\text { gle center) }\end{array}$ & $\begin{array}{l}\text { Gastroduo- } \\
\text { denal ob- } \\
\text { struction }\end{array}$ & $\begin{array}{l}\text { Gastric (122), pan- } \\
\text { creatic (19), } \\
\text { gallbladder (3), bile } \\
\text { duct (3), ampullary } \\
\text { (4), duodenal (2) } \\
\text { cancer, metastasis (1) }\end{array}$ & $70 / 84$ & $67 / 63$ & $71 / 67$ & $\begin{array}{l}\text { Until dead or } \\
\text { the end of the } \\
\text { study }\end{array}$ & Niti-S/Niti-S & $\begin{array}{l}\text { Polyure- } \\
\text { thane } \\
\text { (Partially) }\end{array}$ \\
\hline $\begin{array}{l}\text { Kim et } \\
\text { al., } \\
2010[18]\end{array}$ & Korea & $\begin{array}{l}\text { RCT (Sin- } \\
\text { gle center) }\end{array}$ & $\begin{array}{l}\text { Gastroduo- } \\
\text { denal ob- } \\
\text { struction }\end{array}$ & Gastric cancer (80) & $40 / 40$ & $58 / 57$ & $80 / 78$ & $\begin{array}{l}14.5(1-117) / \\
14(1-114) \\
\text { weeks }\end{array}$ & $\begin{array}{l}\text { Niti-S or } \\
\text { Niti-S } \\
\text { Comvi/Wall } \\
\text { stents or } \\
\text { WallFlex }\end{array}$ & $\begin{array}{l}\text { Polyure- } \\
\text { thane or } \\
\text { PTFE (Par- } \\
\text { tially) }\end{array}$ \\
\hline $\begin{array}{l}\text { Lee et al., } \\
2007[19]\end{array}$ & Korea & $\begin{array}{l}\text { PCS (Sin- } \\
\text { gle center) }\end{array}$ & $\begin{array}{l}\text { Colorectal } \\
\text { obstruction }\end{array}$ & $\begin{array}{l}\text { Colorectal cancer } \\
\text { (70), metastasis of } \\
\text { gastric ( } 8 \text { ) and cervi- } \\
\text { cal (2) cancer }\end{array}$ & $41 / 39$ & $64 / 63$ & $56 / 56$ & NA & Niti-S/Niti-S & $\begin{array}{l}\text { Polyure- } \\
\text { thane } \\
\text { (Partially) }\end{array}$ \\
\hline $\begin{array}{l}\text { Moon et } \\
\text { al., } \\
2010[20]\end{array}$ & Korea & $\begin{array}{l}\text { PCS (Mul- } \\
\text { ti-center) }\end{array}$ & $\begin{array}{l}\text { Colorectal } \\
\text { obstruction }\end{array}$ & $\begin{array}{l}\text { Colorectal cancer } \\
(68)\end{array}$ & $31 / 37$ & $66 / 66$ & $58 / 57$ & $\begin{array}{l}139.5(23-627) / \\
195.5(25-847) \\
\text { days }\end{array}$ & $\begin{array}{l}\text { Niti-S } \\
\text { Comvi/ } \\
\text { Niti-S } \\
\text { D-Weave }\end{array}$ & $\begin{array}{l}\text { PTFE } \\
\text { (Partially) }\end{array}$ \\
\hline $\begin{array}{l}\text { Park et } \\
\text { al., } \\
2010[21]\end{array}$ & Korea & $\begin{array}{l}\text { RCT (Sin- } \\
\text { gle center) }\end{array}$ & $\begin{array}{l}\text { Colorectal } \\
\text { obstruction }\end{array}$ & $\begin{array}{l}\text { Colorectal (120), } \\
\text { gastric (17), pancre- } \\
\text { atic (3), ovarian (5), } \\
\text { urinary bladder (4), } \\
\text { vaginal (1), renal (1) } \\
\text { cancer }\end{array}$ & $75 / 76$ & $62 / 61$ & $52 / 62$ & NA & $\begin{array}{l}\text { Niti-S } \\
\text { Comvi/ } \\
\text { WallFlex }\end{array}$ & $\begin{array}{l}\text { PTFE } \\
\text { (Partially) }\end{array}$ \\
\hline $\begin{array}{l}\text { Isayama } \\
\text { et al., } \\
2004[22]\end{array}$ & Japan & $\begin{array}{l}\text { RCT (Mul- } \\
\text { ti-center) }\end{array}$ & $\begin{array}{l}\text { Biliary ob- } \\
\text { struction }\end{array}$ & $\begin{array}{l}\text { Pancreatic (66), bile } \\
\text { duct (11), gallbladder } \\
\text { (9), papillary (3) } \\
\text { cancer, metastatic } \\
\text { nodes (23) }\end{array}$ & $57 / 55$ & $71 / 70$ & $61 / 56$ & $\begin{array}{l}\text { 246(11-1155) } \\
\text { days }\end{array}$ & $\begin{array}{l}\text { Ultra- } \\
\text { flex/Ultrafle } \\
x\end{array}$ & $\begin{array}{l}\text { Polyure- } \\
\text { thane } \\
\text { (Partially) }\end{array}$ \\
\hline $\begin{array}{l}\text { Telford } \\
\text { et al., } \\
2010[23]\end{array}$ & $\begin{array}{l}\text { Canada, } \\
\text { USA }\end{array}$ & $\begin{array}{l}\text { RCT (Mul- } \\
\text { ti-center) }\end{array}$ & $\begin{array}{l}\text { Biliary ob- } \\
\text { struction }\end{array}$ & $\begin{array}{l}\text { Majority of pancre- } \\
\text { atic cancer (106) }\end{array}$ & $68 / 61$ & $66 / 65$ & $56 / 49$ & $\begin{array}{l}201(0-1302) / \\
125(0-793) \\
\text { days }\end{array}$ & $\begin{array}{l}\text { Wallstents/ } \\
\text { Wallstents }\end{array}$ & $\begin{array}{l}\text { Silicone } \\
\text { (Partially) }\end{array}$ \\
\hline $\begin{array}{l}\text { Kullman } \\
\text { et al., } \\
2010[24]\end{array}$ & Sweden & $\begin{array}{l}\text { RCT (Mul- } \\
\text { ti-center) }\end{array}$ & $\begin{array}{l}\text { Biliary ob- } \\
\text { struction }\end{array}$ & $\begin{array}{l}\text { Pancreatic (307), bile } \\
\text { duct (22), gallbladder } \\
\text { (11), ampullary (17) } \\
\text { cancer, metastatic } \\
\text { nodes (34), unknown } \\
\text { (9) }\end{array}$ & $200 / 200$ & $79 / 76$ & $44 / 46$ & 12 months & $\begin{array}{l}\text { Nitinel- } \\
\text { la/Nitinella }\end{array}$ & $\begin{array}{l}\text { Polycar- } \\
\text { bonate-poly } \\
\text { urethane } \\
\text { (Partially) }\end{array}$ \\
\hline $\begin{array}{l}\text { Krokidis } \\
\text { et al., } \\
2010[25]\end{array}$ & $\begin{array}{l}\text { Greece, } \\
\text { Italy }\end{array}$ & $\begin{array}{l}\text { RCT (Mul- } \\
\text { ti-center) }\end{array}$ & $\begin{array}{l}\text { Biliary ob- } \\
\text { struction }\end{array}$ & $\begin{array}{l}\text { Extrahepatic cholan- } \\
\text { giocarcinoma (60) }\end{array}$ & $30 / 30$ & $67 / 64$ & $67 / 53$ & $\begin{array}{l}212(45-675) \\
\text { days }\end{array}$ & $\begin{array}{l}\text { Via- } \\
\text { bil/Wallsten } \\
\mathrm{t}\end{array}$ & $\begin{array}{l}\text { PTFE/FEP } \\
\text { (Fully) }\end{array}$ \\
\hline $\begin{array}{l}\text { Krokidis } \\
\text { et al., } \\
2011[26]\end{array}$ & $\begin{array}{l}\text { Greece, } \\
\text { Italy }\end{array}$ & $\begin{array}{l}\text { RCT (Mul- } \\
\text { ti-center) }\end{array}$ & $\begin{array}{l}\text { Biliary ob- } \\
\text { struction }\end{array}$ & $\begin{array}{l}\text { Pancreatic head } \\
\text { cancer }(80)\end{array}$ & $40 / 40$ & $64 / 65$ & $58 / 10$ & $\begin{array}{l}\text { 192(104-603) } \\
\text { days }\end{array}$ & $\begin{array}{l}\text { Via- } \\
\text { bil/Luminex } \\
x\end{array}$ & $\begin{array}{l}\text { PTFE/FEP } \\
\text { (Fully) }\end{array}$ \\
\hline
\end{tabular}

Data refer to number of patients, mean age, male gender, follow-up, and stent type with covered/bare stents. RCT, randomized controlled trial; PCS, prospective cohort study; NA, data not available; PTFE, polytetrafluoroethylene; FEP, fluorinated-ethylene-propylene. 
Table 2. Methodological Quality of Included Studies.

\begin{tabular}{|c|c|c|c|c|c|c|c|c|c|}
\hline Study & $\begin{array}{l}\text { Adequate } \\
\text { sequence } \\
\text { generation }\end{array}$ & $\begin{array}{l}\text { Allocation } \\
\text { concealment }\end{array}$ & Blinding & $\begin{array}{l}\text { Incomplete } \\
\text { outcome data } \\
\text { addressed }\end{array}$ & $\begin{array}{l}\text { Free of } \\
\text { selective } \\
\text { reporting }\end{array}$ & $\begin{array}{l}\text { Free from } \\
\text { baseline } \\
\text { imbalance }\end{array}$ & $\begin{array}{l}\text { Free from } \\
\text { early } \\
\text { stopping }\end{array}$ & $\begin{array}{l}\text { Sample } \\
\text { size calcu- } \\
\text { lation }\end{array}$ & $\begin{array}{l}\text { Free from } \\
\text { sources of } \\
\text { funding bias }\end{array}$ \\
\hline Vakil et al., 2001[16] & Unclear & Yes & No & Yes & Yes & Yes & Yes & Yes & Yes \\
\hline Lee et al., 2009[17] & No & No & No & Yes & Yes & Yes & Yes & No & Yes \\
\hline Kim et al., 2010[18] & Yes & Yes & No & No & Yes & Yes & Yes & Yes & Yes \\
\hline Lee et al., 2007[19] & No & No & No & Yes & Yes & Yes & Yes & No & Yes \\
\hline Moon et al., 2010[20] & No & No & No & Yes & Yes & Yes & Yes & No & Yes \\
\hline Park et al., 2010[21] & Yes & Unclear & Unclear & Yes & Yes & Yes & Yes & Yes & Yes \\
\hline Isayama et al., 2004[22] & Yes & Yes & Unclear & Yes & Yes & Yes & No & Yes & Yes \\
\hline Telford et al., 2010[23] & Yes & Yes & Yes & Yes & Yes & Yes & Yes & Yes & No \\
\hline Kullman et al., 2010[24] & Yes & Yes & Unclear & Yes & Yes & Yes & Yes & Yes & Yes \\
\hline Krokidis et al., 2010[25] & Yes & Unclear & Unclear & Yes & Yes & Yes & Yes & No & Yes \\
\hline Krokidis et al., 2011[26] & Yes & Unclear & Unclear & Yes & Yes & Yes & Yes & Yes & Yes \\
\hline
\end{tabular}

Table 2 shows the quality indices of the studies. No one met all quality measures; but all the studies halffulfilled. The main weakness lay in the reporting on allocation concealment and blinding. Participants were blinded to stent assignment in only one study [23]. However, the methodological quality of the included studies was overall high.

\section{Primary outcomes}

Seven studies with available HRs contributed to the assessment of stent patency. Two studies did not report any necessary statistical information to calculate the HR and its variables [16,19], and another two failed to produce the HR from the Kaplan-Meier curves because of non-accurate follow-up time [17,21]. No significant difference between covered and bare stents was found in HR for time to recurrence of gastroduodenal obstruction ( $\mathrm{HR}=0.87,95 \%$ CI 0.53-1.42), colorectal obstruction ( $\mathrm{HR}=0.89,95 \%$ CI $0.18-4.45)$, and biliary obstruction ( $\mathrm{HR}=0.73,95 \%$ CI $0.41-1.32)$, respectively (Figure 2A).

Six studies with available HRs contributed to the assessment of patient survival. Four studies did not report any necessary statistical information to calculate the HR and its variables [17,19-21], and another one failed to produce the HR from the Kaplan-Meier curve because of its low definition [26]. No significant difference between covered and bare stents was found in HR for death in patients with esophageal obstruction $(\mathrm{HR}=1.80,95 \% \mathrm{CI}$ 0.73-4.44), gastroduodenal obstruction (HR $=0.83,95 \%$ CI $0.55-1.26)$, and biliary obstruction (HR $=0.99,95 \%$ CI $0.77-1.28)$, respectively (Figure 2B).

\section{Secondary outcomes}

Eight studies and five studies reported data on technical success and clinical success respectively.
High success rates were achieved by using both covered and bare stents. Pooled results showed no significant disparities between the both groups for technical (Figure 3A) and clinical (Figure 3B) success rates in each subgroup.

All eleven studies reported data on tumor ingrowth. Pooled results showed significantly lower incidence of tumor ingrowth by using covered stents than bare stents in all digestive tract segments (Figure 4).

Ten studies reported data on tumor overgrowth. Pooled results showed significantly higher incidence of tumor overgrowth by using covered stents than bare stents in biliary obstruction ( $R R=2.03,95 \%$ CI 1.08-3.78), but not in gastroduodenal $(R R=2.10,95 \%$ CI $0.45-9.79$ ) and colorectal $(\mathrm{RR}=2.68,95 \% \mathrm{CI}$ 0.54-13.33) obstruction (Figure 5).

Nine studies reported data on stent migration. Pooled results showed significantly higher incidence of stent migration by using covered stents than bare stents in gastroduodenal $(\mathrm{RR}=5.01,95 \% \mathrm{CI}$ 1.53-16.43), colorectal ( $R R=11.70,95 \%$ CI 2.84-48.27), and biliary ( $R R=8.11,95 \%$ CI 1.47-44.76) obstruction, but not in esophageal obstruction $(\mathrm{RR}=1.88,95 \% \mathrm{CI}$ 0.37-9.50) (Figure 6).

\section{Publication bias}

The $\mathrm{P}$ values for Egger regression test on the endpoints of technical success $(P=0.002)$, tumor ingrowth $(\mathrm{P}<0.001)$, and tumor overgrowth $(\mathrm{P}=0.007)$ suggested that there is statistical evidence of publication bias. The Egger's $P$ values on the endpoints of stent patency $(\mathrm{P}=0.076)$ and migration $(\mathrm{P}=0.062)$ were indicative of potential publication bias. There was no detection of publication bias only on the endpoints of patient survival $(\mathrm{P}=0.521)$ and clinical success $(\mathrm{P}=0.820)$. 
A

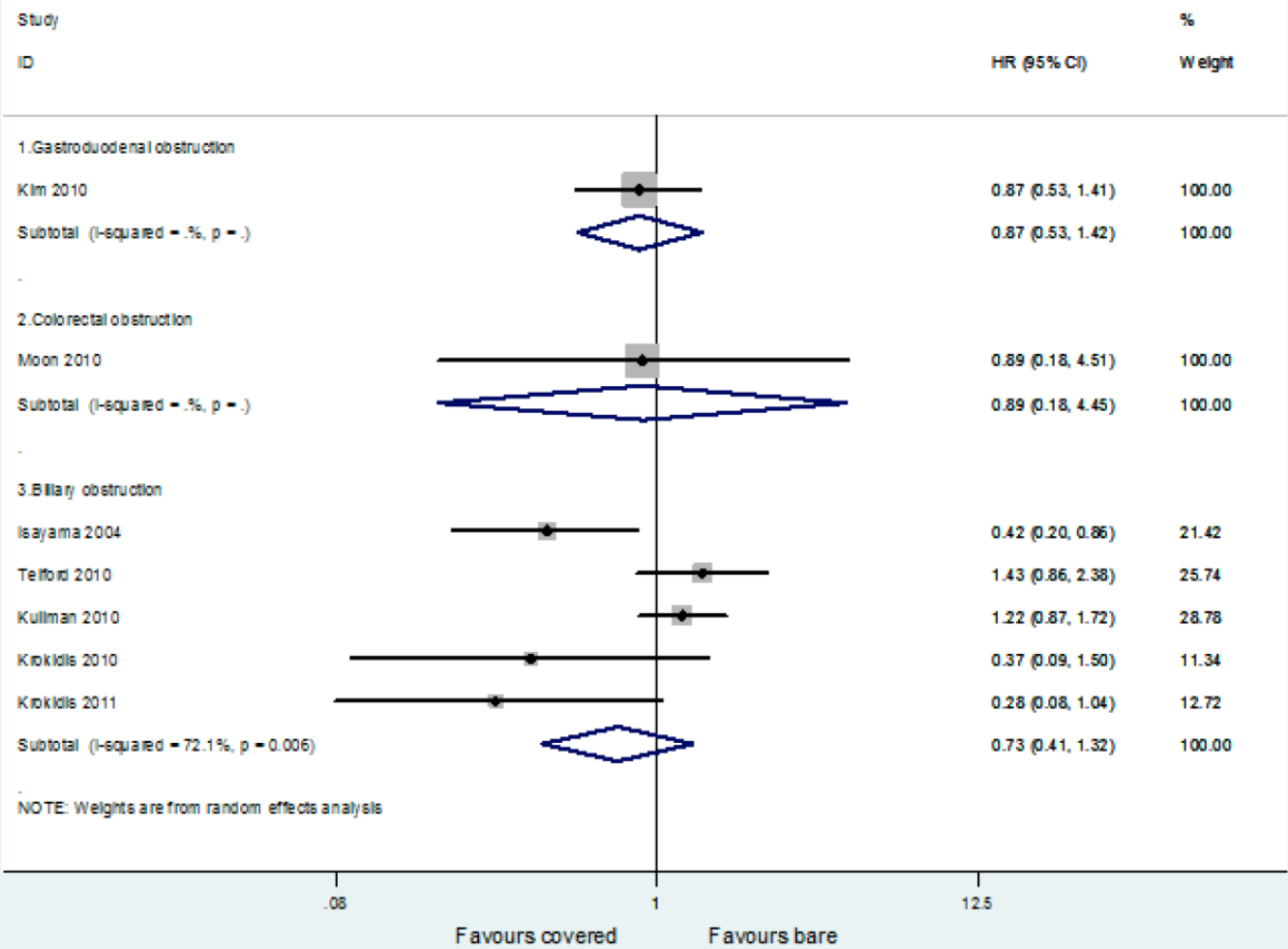

B

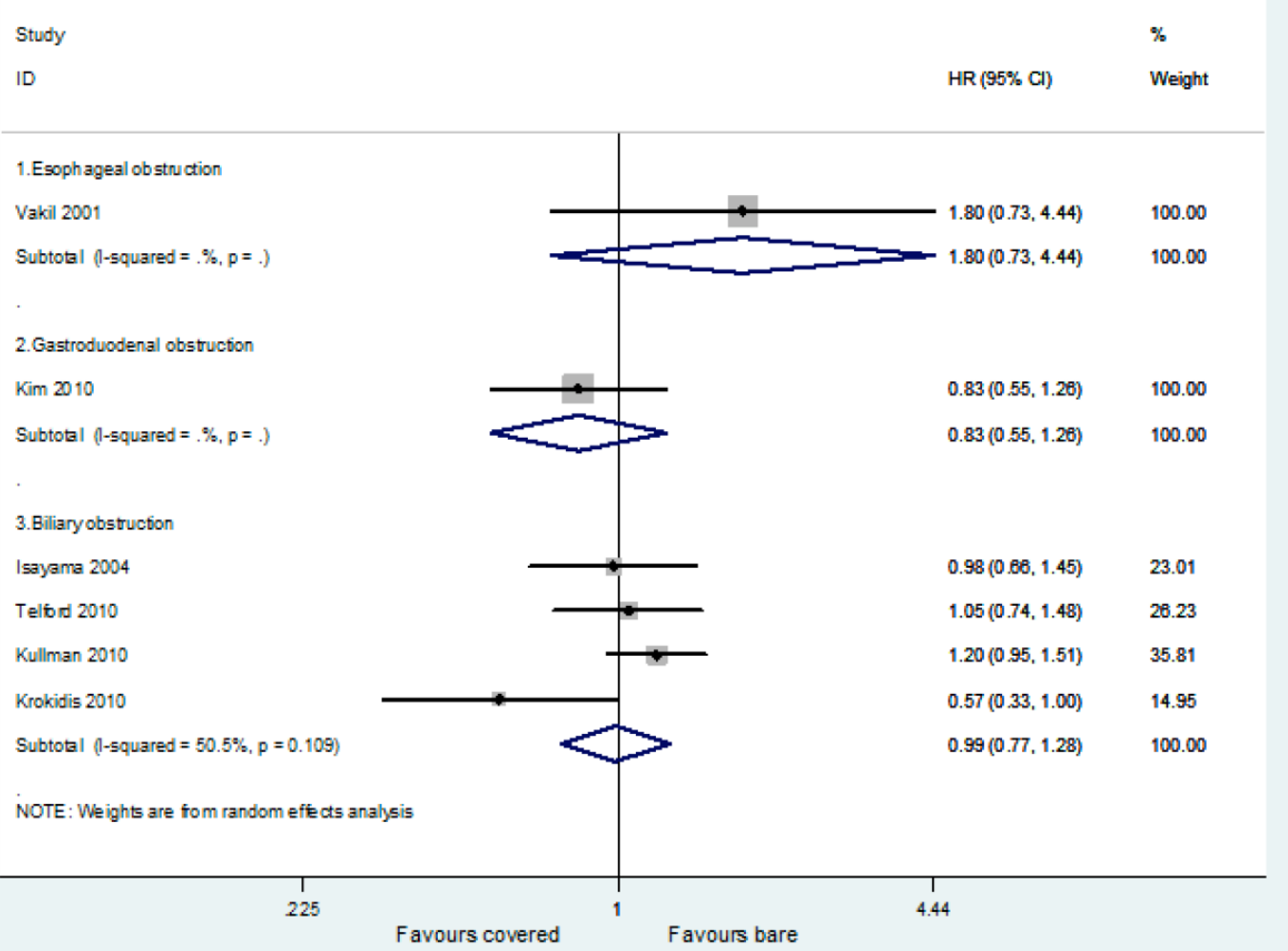

Fig 2. Forest plots for patency (A) and survival (B) rate. 


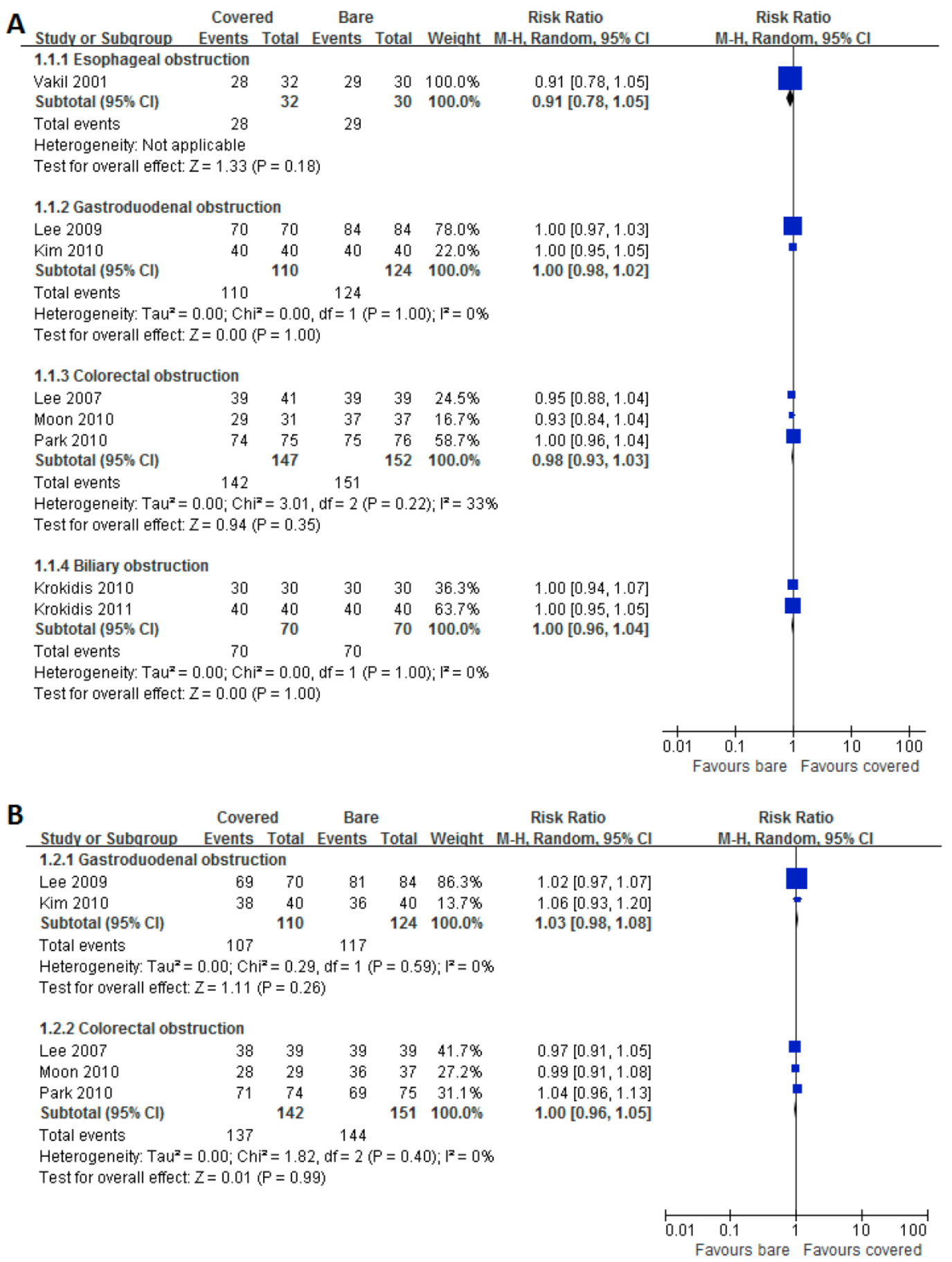

Fig 3. Forest plots for technical $(A)$ and clinical $(B)$ success rate. 


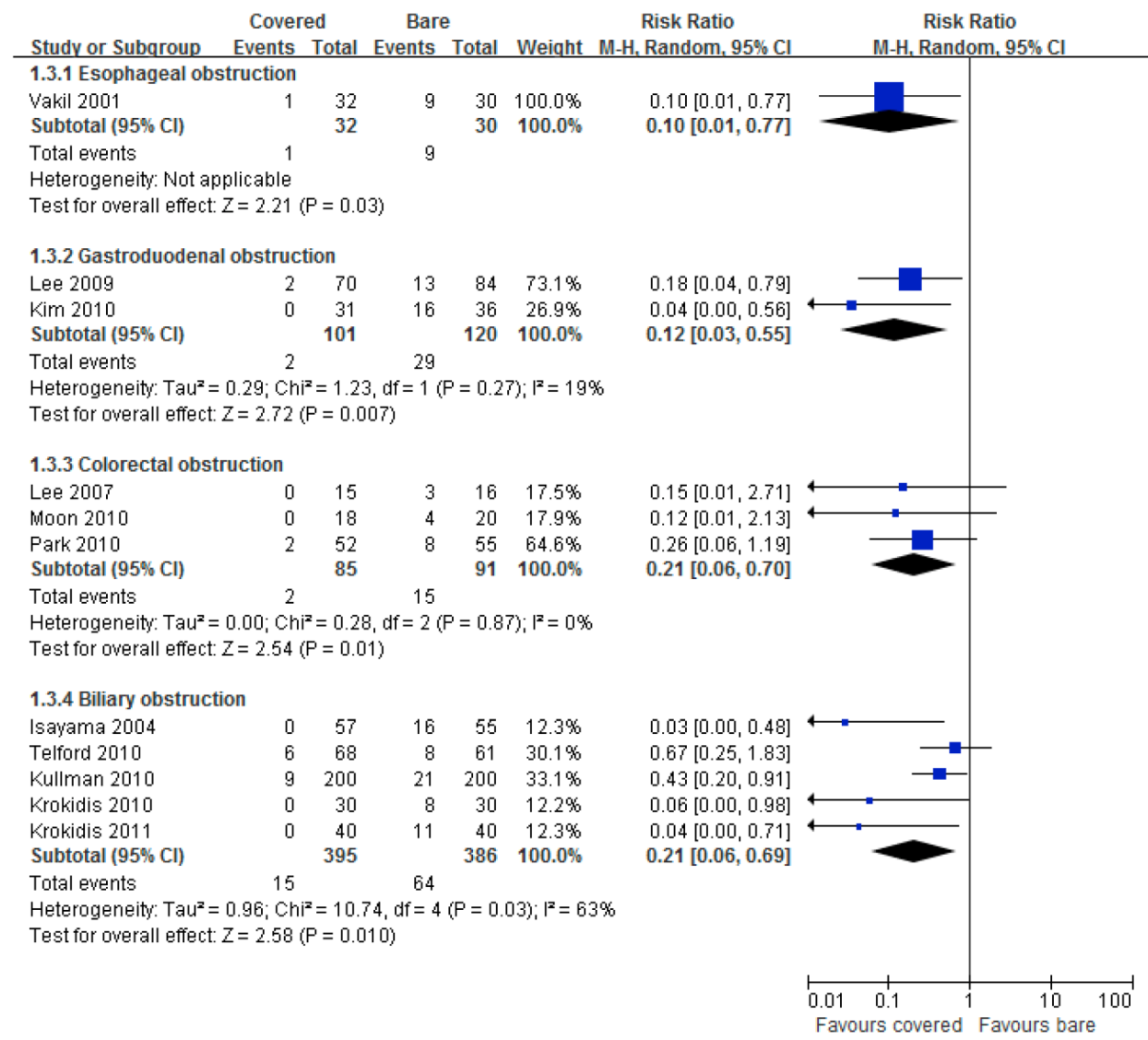

Fig 4. Forest plots for ingrowth rate.

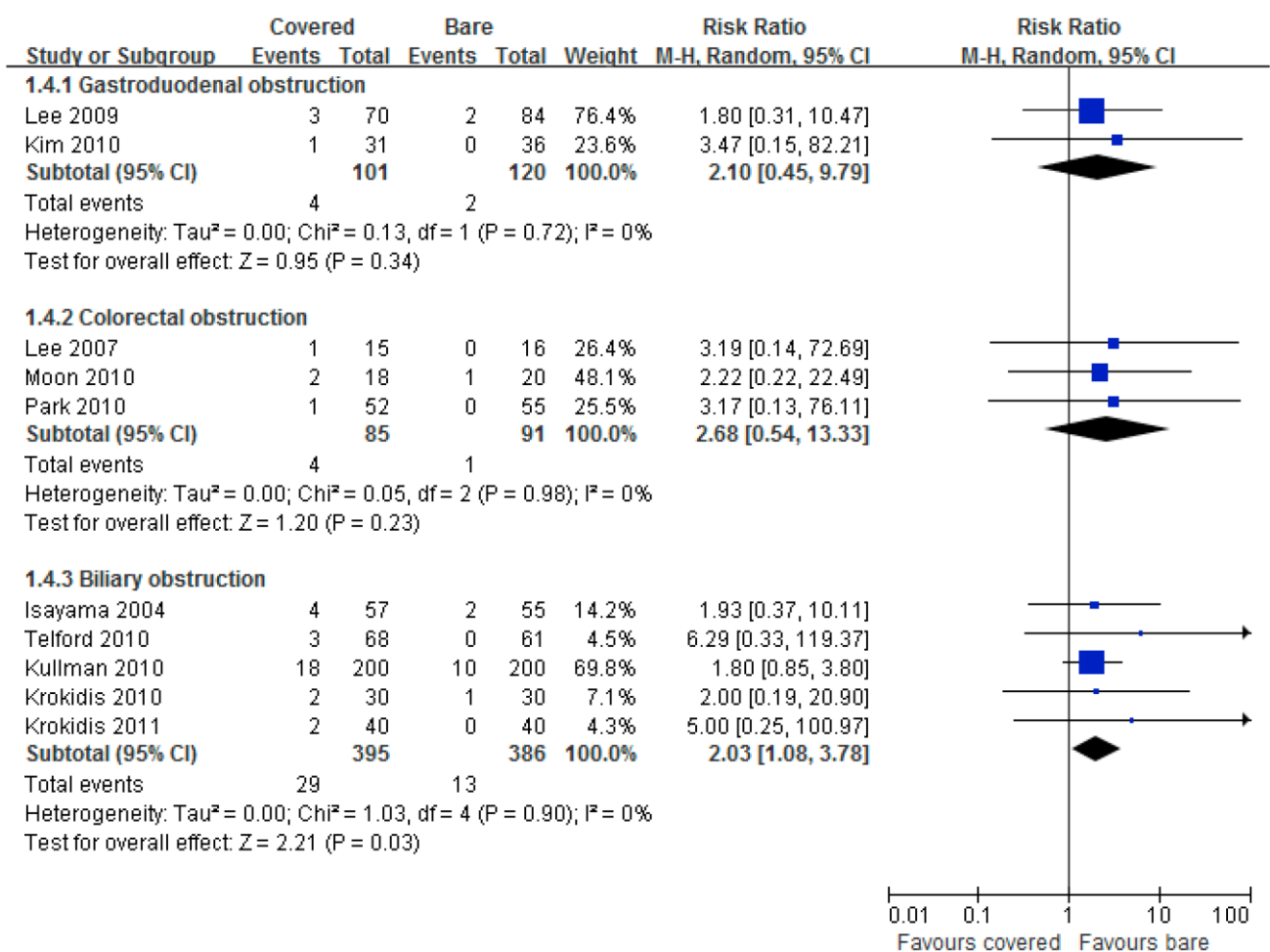

Fig 5. Forest plots for overgrowth rate. 


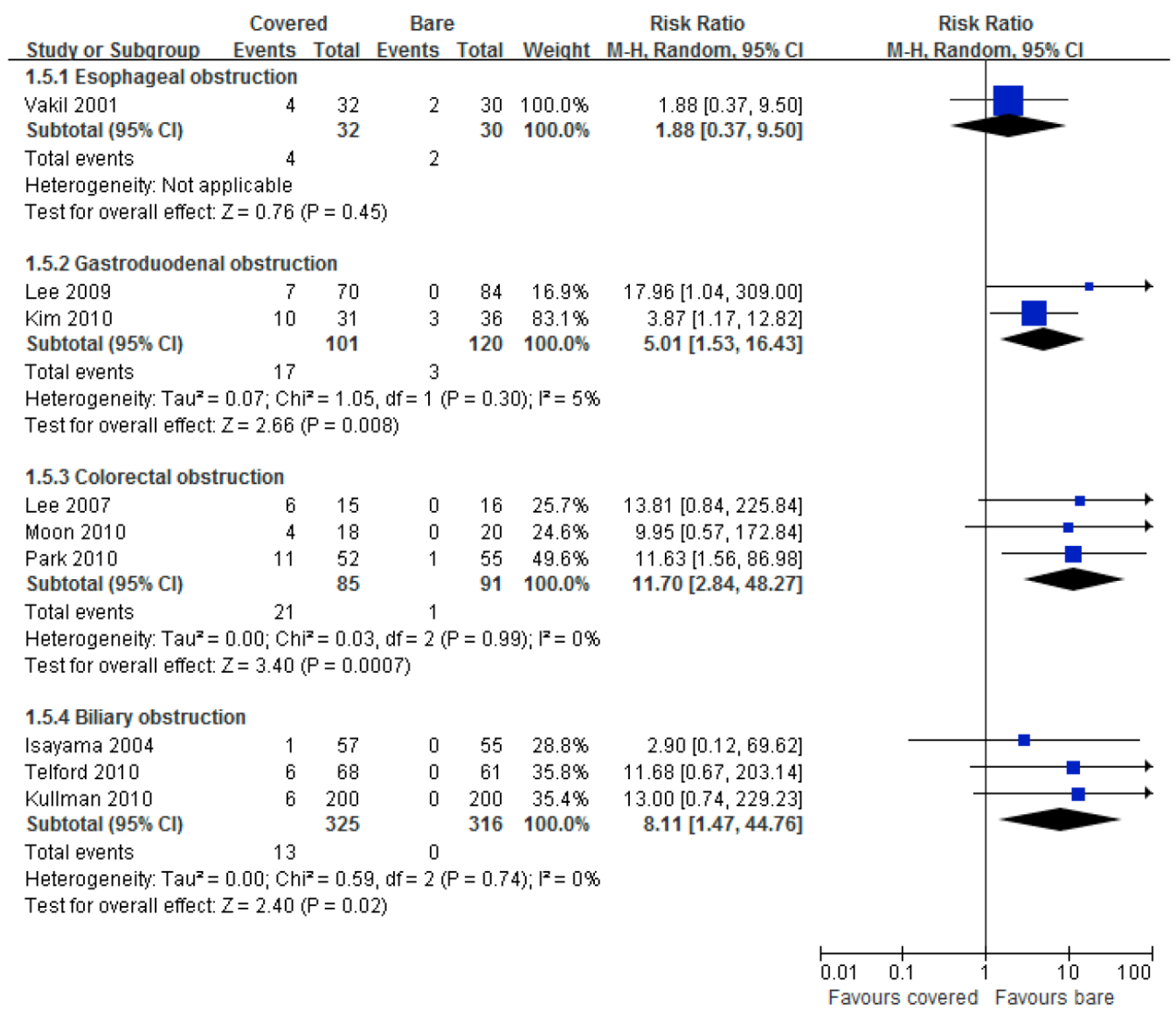

Fig 6. Forest plots for migration rate.

\section{Discussion}

This systematic review shows that covered SEMS are equivalent to bare SEMS in terms of technical success, clinical success, long-term patency and survival rates for the palliative treatment of malignant obstruction in the digestive tract, although bare stents are more prone to tumor ingrowth, whereas covered stents have the higher risk of stent migration and tumor overgrowth relatively. Our pooled results on the primary endpoints are different with those in the two previous meta-analyses, although the secondary endpoints are in same trends between ours and theirs. That is because we chose HR as summary measure concerning stent patency and patient survival, while Saleem et al and Zhang et al used mean weighted difference. As mentioned above, HR can more truly reflect the risk of time-to-events such as death.

Currently, advances in stent design have resulted in substantially increasing use of stents for a variety of malignant gastrointestinal obstruction $[2,27,28]$. Covered SEMS were designed in order to overcome the shortage of uncovered stents and prolong stent patency. But in our study, covered stents did not have any advantage over bare stents on reducing stent dysfunction and extending patients' survival. It is well-known that the main mechanisms influencing stent patency are tumor ingrowth, tumor overgrowth, and stent migration. The benefit of decreased lumen re-stenosis rate in the covered SEMS group compared with bare SEMS group was offset by the higher migration and overgrowth rate of the covered SEMS. In the current study, tumor in growth occurred more frequently with bare stent than covered stent for every segment of the digestive tract. Whereas stent migration took place oftener with covered stent than bare stent in each site of the digestive tract except for esophagus. Migration rates were similar between the two types of stents for esophageal obstruction, because majority of the stents were placed at the gastroesophageal junction where the lower end of the stent lay free in the stomach and could not integrate into the wall of the organ [16]. So patients with cancerous gastrointestinal obstruction could not ultimately obtain more survival benefit from the covered stents. Moreover, biofilms might develop and attach the coating surface in a similar way to those in plastic stents $[2,9]$. Nevertheless, cov- 
ered stents were easier to be removed if necessary than bare stents whose metal meshes were embedded in the tumor tissue.

Many efforts have been made to improve covered SEMS with better migration-resistance and longer stent patency. Recent covered stents were designed in a dumbbell shape with flange ends and to have a proximal uncovered portion for the prevention of migration [2]. In our included studies, all the covered stents were partially coated except for those in two studies by Krokidis et al $[25,26]$, who did not report data on stent migration. However, a recent meta-analysis found no disparity in all measured outcomes between fully and partially covered stents in bile duct [9]. Stent with covered material inserted between two layers of metal nets (Niti-S Comvi), which is designed to slow tumor ingrowth and at the same time to minimize the risk of migration, was used in a few of the enrolled studies. It was demonstrated that the efficacy of this new stent was similar to other two-layer covered stent [29,30]. In addition, stents made of stainless steel might migrate more often than those made of nitinol [24,31]. However, all of the covered stents in our meta-analysis were nitinol ones. Although stents covered with polytetrafluoroethylene seems to be less membrane damage by tumor ingrowth than other materials, the role that different coatings plays in stent outcomes is still undetermined $[2,9]$. On the other hand, stent-in-stent technique has become an alternative therapy for tumor ingrowth. The additional insertion of a covered stent to the inside of a bare stent, or simultaneous deployment of bare and covered stent was reported to be valid for the prevention of stent migration and tumor ingrowth $[32,33]$.

Several limitations existed in this meta-analysis. First, the major limitation of the study is the comparison of different segments of the digestive tract. However, due to the same practical principal of SEMS throughout the entire digestive tract, and the similar pathological characteristic and stent design for each site of the digestive tract, it is necessary and feasible to compare the efficacy of stents involving all the digestive tract. Furthermore, we pooled the results separately for each segment of the digestive tract and saw if there was same trend towards each endpoint. Secondly, the numbers of included studies were few, especially for malignant esophageal, gastroduodenal and colorectal obstruction. It might be underpowered to assess their summary statistics in the subgroup analyses. Thirdly, not all the studies provided data on each endpoint except for tumor ingrowth. Fourthly, there was significant heterogeneity in reporting of primary outcomes, suggesting that some factors other than stent itself in the different sites of the digestive tract might influence patients' prognosis. We could not adjust these variables accordingly. Fifthly, the majority of the studies reviewed failed to report whether participants or outcome assessors were blinded to the stent assignment. Lack of blinding could lead to detection bias. Finally, there was evident publication bias in this meta-analysis. So the results should be interpreted with caution.

However, our study is the first systematic review concerning SEMS placed in all digestive tract segments, giving us a full view of the comparison between covered and bare stents for malignant gastrointestinal obstruction. The methodological quality of the included studies and the number of patients included in this meta-analysis were overall high.

In conclusion, both covered and bare SEMS are comparable in efficacy for the palliative treatment of malignant obstruction in the digestive tract. Each type of the stents has its own merit and demerit relatively. More high quality RCTs are needed to confirm our findings. Further development of stent design is also necessary to conquer the current defects.

\section{Supplementary Material}

The full electronic search strategy for PubMed database, and PRISMA 2009 Checklist. http://www.medsci.org/v10p0825s1.pdf

\section{Acknowledgements}

This study was funded in part by the National Natural Science Foundation of China (No. 81172062 and No. 81000988).

\section{Competing Interests}

The authors have declared that no competing interest exists.

\section{References}

1. Baron TH. Expandable metal stents for the treatment of cancerous obstruction of the gastrointestinal tract. N Engl J Med. 2001; 344: 1681-7.

2. Chun HJ, Kim ES, Hyun JJ, et al. Gastrointestinal and biliary stents. J Gastroenterol Hepatol. 2010; 25: 234-43.

3. Moss AC, Morris E, Leyden J, et al. Do the benefits of metal stents justify the costs? A systematic review and meta-analysis of trials comparing endoscopic stents for malignant biliary obstruction. Eur J Gastroenterol Hepatol. 2007; 19: 1119-24.

4. Yakoub D, Fahmy R, Athanasiou T, et al. Evidence-based choice of esophageal stent for the palliative management of malignant dysphagia. World J Surg. 2008; 32: 1996-2009.

5. Saranovic D, Djuric-Stefanovic A, Ivanovic A, et al. Fluoroscopically guided insertion of self-expandable metal esophageal stents for palliative treatment of patients with malignant stenosis of esophagus and cardia: comparison of uncovered and covered stent types. Dis Esophagus. 2005 ; 18 : 230-8.

6. Maetani I, Ukita T, Tada T, et al. Metallic stents for gastric outlet obstruction: reintervention rate is lower with uncovered versus covered stents, despite similar outcomes. Gastrointest Endosc. 2009; 69: 806-12. 
7. Park do H, Kim MH, Choi JS, et al. Covered versus uncovered Wallstent for malignant extrahepatic biliary obstruction: a cohort comparative analysis. Clin Gastroenterol Hepatol. 2006; 4: 790-6.

8. Choi JS, Choo SW, Park KB, et al. Interventional management of malignant colorectal obstruction: use of covered and uncovered stents. Korean J Radiol. 2007; 8: 57-63.

9. Saleem A, Leggett CL, Murad MH, et al. Meta-analysis of randomized trials comparing the patency of covered and uncovered self-expandable metal stents for palliation of distal malignant bile duct obstruction. Gastrointest Endosc. 2011; 74: 321-7.

10. Zhang Y, Shi J, Shi B, et al. Comparison of efficacy between uncovered and covered self-expanding metallic stents in malignant large bowel obstruction: a systematic review and meta-analysis. Colorectal Dis. 2012; 14: e367-74.

11. Liberati A, Altman DG, Tetzlaff J, et al. The PRISMA statement for reporting systematic reviews and meta-analyses of studies that evaluate health care interventions: explanation and elaboration. Ann Intern Med. 2009; 151: W65-94.

12. Tierney JF, Stewart LA, Ghersi D, et al. Practical methods for incorporating summary time-to-event data into meta-analysis. Trials. 2007; 8: 16.

13. Parmar MK, Torri V, Stewart L. Extracting summary statistics to perform meta-analyses of the published literature for survival endpoints. Stat Med. 1998; 17: 2815-34.

14. Gonzalez R, Zamora J, Gomez-Camarero J, et al. Meta-analysis: combination endoscopic and drug therapy to prevent variceal rebleeding in cirrhosis. Ann Intern Med. 2008; 149: 109-22.

15. Yang Z, Han G, Wu Q, et al. Patency and clinical outcomes of transjugular intrahepatic portosystemic shunt with polytetrafluoroethylene-covered stents versus bare stents: a meta-analysis. J Gastroenterol Hepatol. 2010; 25: 1718-25.

16. Vakil N, Morris AI, Marcon N, et al. A prospective, randomized, controlled trial of covered expandable metal stents in the palliation of malignant esophageal obstruction at the gastroesophageal junction. Am J Gastroenterol. 2001; 96: 1791-6.

17. Lee KM, Choi SJ, Shin SJ, et al. Palliative treatment of malignant gastroduodenal obstruction with metallic stent: prospective comparison of covered and uncovered stents. Scand J Gastroenterol. 2009; 44: 846-52.

18. Kim CG, Choi IJ, Lee JY, et al. Covered versus uncovered self-expandable metallic stents for palliation of malignant pyloric obstruction in gastric cancer patients: a randomized, prospective study. Gastrointest Endosc. 2010; 72: 25-32.

19. Lee KM, Shin SJ, Hwang JC, et al. Comparison of uncovered stent with covered stent for treatment of malignant colorectal obstruction. Gastrointest Endosc. 2007; 66: 931-6.

20. Moon CM, Kim TI, Lee MS, et al. Comparison of a newly designed double-layered combination covered stent and D-Weave uncovered stent for decompression of obstructive colorectal cancer: a prospective multicenter study. Dis Colon Rectum. 2010; 53: 1190-6.

21. Park S, Cheon JH, Park JJ, et al. Comparison of efficacies between stents for malignant colorectal obstruction: a randomized, prospective study. Gastrointest Endosc. 2010; 72: 304-10.

22. Isayama $H$, Komatsu $Y$, Tsujino $T$, et al. A prospective randomised study of "covered" versus "uncovered" diamond stents for the management of distal malignant biliary obstruction. Gut. 2004; 53: 729-34.

23. Telford JJ, Carr-Locke DL, Baron TH, et al. A randomized trial comparing uncovered and partially covered selfexpandable metal stents in the palliation of distal malignant biliary obstruction. Gastrointest Endosc. 2010; 72: 907-14.

24. Kullman E, Frozanpor F, Soderlund C, et al. Covered versus uncovered self-expandable nitinol stents in the palliative treatment of malignant distal biliary obstruction: results from a randomized, multicenter study. Gastrointest Endosc. 2010; 72: 915-23.

25. Krokidis M, Fanelli F, Orgera G, et al. Percutaneous treatment of malignant jaundice due to extrahepatic cholangiocarcinoma: covered Viabil stent versus uncovered Wallstents. Cardiovasc Intervent Radiol. 2010; 33: 97-106.

26. Krokidis M, Fanelli F, Orgera G, et al. Percutaneous palliation of pancreatic head cancer: randomized comparison of ePTFE/FEP-covered versus uncovered nitinol biliary stents. Cardiovasc Intervent Radiol. 2011; 34: 352-61.

27. Vlavianos $\mathrm{P}$, Zabron A. Clinical outcomes, quality of life, advantages and disadvantages of metal stent placement in the upper gastrointestinal tract. Curr Opin Support Palliat Care. 2012; 6: 27-32.

28. Jaganmohan $S$, Lee JH. Self-expandable metal stents in malignant biliary obstruction. Expert Rev Gastroenterol Hepatol. 2012; 6: 105-14.
29. Isayama $H$, Kawabe $T$, Nakai $Y$, et al. Management of distal malignant biliary obstruction with the ComVi stent, a new covered metallic stent. Surg Endosc. 2010; 24: 131-7.

30. Verschuur EML, Repici A, Kuipers EJ, et al. New design esophageal stents for the palliation of dysphagia from esophageal or gastric cardia cancer: a randomized trial. Am J Gastroenterol. 2008; 103: 304-12.

31. Isayama $\mathrm{H}$, Mukai $\mathrm{T}$, Itoi $\mathrm{T}$, et al. Comparison of partially covered nitinol stents with partially covered stainless stents as a historical control in a multicenter study of distal malignant biliary obstruction: the WATCH study. Gastrointest Endosc. 2012; 76: 84-92.

32. Song GA, Kang DH, Kim TO, et al. Endoscopic stenting in patients with recurrent malignant obstruction after gastric surgery: uncovered versus simultaneously deployed uncovered and covered (double) self-expandable metal stents. Gastrointest Endosc. 2007; 65: 782-7.

33. Shim CS, Cho JY, Jung IS, et al. Through-the-scope double colonic stenting in the management of inoperable proximal malignant colonic obstruction: a pilot study. Endoscopy. 2004; 36: 426-31. 